\title{
Challenges of implementing e-learning in a Pakistani university
}

\author{
Ijaz A. Qureshi
}

Faculty of Management Sciences

HITECH University, Taxila Cantt, Pakistan

E-mail: IjazQureshi@Cal.Berkeley.Edu

\section{Khola Ilyas*}

Iqra University, Islamabad, Pakistan

E-mail: Khola_illy@hotmail.com

\section{Robina Yasmin}

Iqra University, Islamabad, Pakistan

E-mail: robina@iqraisb.edu.pk

\author{
Michael Whitty \\ University of San Francisco, USA \\ University of Detroit, USA \\ E-mail: michael.whitty@udmercy.edu
}

*Corresponding author

\begin{abstract}
The integration of e-learning programs into the educational system has reshaped the process of acquisition and dissemination of knowledge throughout the society. Although numbers of researchers approve of the effectiveness of e-learning integration in terms of the innovation it offers to engage with students does not guarantee the success of e-learning programs. This can be observed in developing countries like Pakistan, which have not yet been able to benefit fully from the advantages of e-learning. Though the importance of this issue is theoretically highlighted in research, empirical evidence is scarce particularly regarding developing countries like Pakistan.

Therefore, the purpose of this study is to identify the issues, related to elearning through the feedback captured from students and provide strategies to successfully overcome the issues. In order to achieve this purpose, a number of issues prevailing in a Pakistani private university were identified through in depth literature review and discussion with the students. The findings demonstrated electricity failure and English proficiency as the most significant barriers to successful integration of e-learning. Lastly conclusion was drawn and suggestions were made on the basis of issues identified.
\end{abstract}

Keywords: e-Learning; Higher education; Pakistani university

Biographical notes: Dr. Ijaz A. Qureshi is an Associate Professor at HITECH University, Taxila Cantt, Pakistan and Principal at IAQ Consulting Company. His interests include RFID and Privacy and Security; VoIP and the Future of Telecom Industry; Disruptive Technologies and High-Tech Industry; Blended 
Learning and Traditional Schooling; E-Learning/M-Learning and Intellectual Property rights and Innovation.

Khola Ilyas is an M.Sc student at Iqra University Islamabad and research associate at JFK Institute of Technology and Management, Islamabad. The subject of her Thesis is "Application of TAM in m-learning: A gender based approach". Her interests include e-Learning, m-Learning and learning through social media.

Dr. Robina Yasmin is an Assistant Professor at Iqra University Islamabad. She earned her PhD degree from Aichi - Gakuin University, Japan. Her interests include human resource management and learning technologies.

Professor Michael Whitty has extensive experience in relating Jesuit values to the business community as well as academia. He teaches at the University of Detroit Mercy and the University of San Francisco where he teaches ethics theory for the Saint Ignatius Institute. He also is a senior research associate at The Institute for the Future of Work.

\section{Introduction}

The robust growth of information technology has made it possible and a requirement for learning to occur quickly. Meeting new issues and challenges requires innovative thinking about acquiring necessary skills and knowledge as well as the ability to manage efficiently within the available resources. E-learning is the outcome of the innovative transfer of knowledge and learning which has been greatly influenced with the advent of Internet and Information and Communication Technologies (ICT).

A recent trend observed in higher education is the introduction of e-learning systems to provide students with online access to learning contents. The major driving forces behind this trend are the changing demographic factors of the students, changing conditions for education delivery and the innovation in technology itself (Concannon, Flynn, \& Campbell, 2009). In order to keep pace with the changing trends, educational systems all around the world are in the process of integrating ICTs to enhance the learning experience of students. Although a lot of focus has been directed towards highlighting the positive effects of e-learning, there is a need to be cautious about the frustration and dissatisfaction that may be caused due to this shift away from traditional ways.

Surry, Ensminger, and Haab (2005) suggest that integration of instructional technology in education may face numerous barriers, such as infrastructure of technology, students' competence, technology satisfaction and instructors' motivation. No matter how effective the technology is, it serves little purpose without proper implementation. Many higher education institutions have failed because of poor strategies, high cost of technology, resistance to change, competition and poor delivery of courses (Elloumi, 2004; Saadé, 2003). These issues become more pronounced for developing countries, like Pakistan, which have limited resources and technical expertise as compared to developed countries. Still, the experience produced by e-learning in education goes way beyond entertainment (Garrison \& Anderson, 2003). For this reason, more and more universities around the world are likely to embrace e-learning. 
However, with little government spending on education and low literacy rates, Pakistan faces the challenge of effectively integrating e-learning systems into the education system. According to Ndubisi (2004) investment in infrastructure, training IT staff and content development is not enough for successful adoption of e-learning. Merely offering courses online and attempting to reproduce the classroom experience may cause unexpected difficulties. Persistent frustration and dissatisfaction of students towards the use of web based learning is often due to delayed feedback. This requires more research focused on students to identify their preferences and views in terms of elearning.

Therefore, this paper aims to identify the issues and challenges faced by a Pakistani private university in establishing e-learning as a successful medium of imparting education. This study helps the educational institutions in addressing the identified issues through recommended strategies so that wasting of resources, time and skills could be prevented.

\section{1. e-Learning}

e-Learning, a general term for education, training and information emphasizes assembling skills and knowledge (Iqbal \& Ahmad, 2010). It is a method that evolved from distance education which allows knowledge sharing and learning without the constraints of time or place. Different names have been devised for e-learning depending on its usage such as computer-based training (CBT) which was the first addition to traditional instructor-led education. This could include delivery through CD-ROM's as it requires a lot of bandwidth. It was followed by a rise in web based training (WBT), which allowed the users to take trainings comfortably over the internet, and then virtual education. E-learning as a tool for enriching learning and teaching facilitates communication between and among the users and instructors involving work submissions and content delivery (Cysewski, 2010). The ICT rich environment not only provides costeffective access to delivery of knowledge but also highlights the potential of the Internet as a publishing tool. Therefore, learning and technology go hand in hand whereby the absence of any one of the factors would greatly diminish the educational value of elearning.

As Information Technology has become robust and easier to use with time, it has greatly permeated academic activities in higher education. The learning methods have greatly been supported by the use of Internet and web based forums. Literature supports e-learning as a successful way of engaging students with learning and sharing of knowledge (Lewis \& Allan 2005; McConnell, 2006). Based on the literature review, some of the benefits of e-learning are listed below:

- Accessibility

It allows learners to access material when needed and study at their own preferred pace without the stress of missing important information (Roy \& Raymond, 2005).

- Low delivery cost

Once the material is developed and uploaded online it has no expiry date and could be utilized anywhere in the world (Allen, 2011). 
- $\quad$ Bridging the gap

It reduces the gap between theory and practice as many organizations have functional websites providing service online (Johns, 2003).

- Deep learning

Learners are required to critically engage with the bundles of information available online which induces active and deep learning rather than surface learning (Johns, 2003).

- $\quad$ Shared learning

E-learning boosts shared learning by allowing interaction among learners from diverse backgrounds.

\section{- Freedom of speech}

In a study some of the students viewed e-learning as a facilitator of freedom of speech with focus on deep learning (Sweeney, O'Donoghue, \& Whitehead, 2004).

However, technologies bring challenges as well and merely the presence of a technology does not guarantee successful implementation. Therefore, understanding the perceptions of users in the context of technology requirements of their work environment is highly important as the technology considered useful in one environment may not be considered the same in other. It is important to cater to the concerns of the students in order to improve the educational perspectives of e-learning (Al-Mahmood \& McLoughlin, 2004). Therefore, Esichaikul, Lamnoi, and Bechter (2011) proposed the use of adaptive e-learning systems, which allows adaptation of information according to the knowledge and behavior level of the individual user. Otherwise neglecting pertinent issues may result in technical difficulties, students' frustration and resistance to the use of e-learning which may inhibit effective learning.

\subsection{Rationale for e-learning in Pakistani higher education system}

Researchers need to consider the impact of social, cultural and economic issues residing within a country when introducing and integrating e-learning into the educational system (Huntington \& Sudbery 2005). These issues significantly affect the thinking of the users and play an important role in shaping perceptions and uptake of technology.

With a population of 170 million and an adult literacy rate of $57.9 \%$ (Economic survey, 2010), Pakistan falls at 160th position among other countries in terms of its literacy rate. Access to basic and higher education has been a constant challenge for the country's ability to build up its human capital and evolve into a knowledge based economy. Furthermore, its limited educational budget, $2.1 \%$ of GDP, aggravates the situation and reduces the likelihood of investment in infrastructures to support shift from traditional educational systems to new modes of education. In rural areas the state of affairs is even worse with a literacy rate of $48 \%$ as a result of lack of educational facilities, quality teachers and low awareness of the importance of education (Economic survey, 2010).

The Government of Pakistan realized by the end of 2000 that its dream of "Education for All" would not come into reality without the induction of the latest technologies and new ideas in the traditional education system (Anwar, Greer, \& Brooks, 
2006). By anticipating the significance of e-learning, the Government of Pakistan established Virtual University with the aim of imparting education to full time working professionals in all regions of Pakistan. The University is utilizing a mix of e-learning and traditional education with face to face meetings to meet the needs of students. The study carried out by Anwar, Hukamdad, and Niwaz (2011) found lack of student teacher interaction, better equipped virtual campuses of major cities as compared to campuses of small cities, weak marketing and course work inconsistent with market demand. Therefore, the acceptance of this form of education among the general public and the employers was quite low.

Gradually, other universities began shifting towards the use of e-learning techniques such as Learning Management Systems (LMS) and video conferencing as an alternative to conventional university education. Although these initiatives have been encouraging, Pakistan still has to go a long way to reap the benefits of e-learning in order to compete with international educational standards. Failure to take advantage of the possibilities offered by e-learning presses the need for in depth review of the underlying issues. Based on a literature review and survey several e-learning issues relevant to the context of Iqra University have been identified and explained below:

\section{- Technical Difficulties}

Technical difficulties are a significant aspect of implementation and integration of e-learning technologies in education system. They include installation, availability of latest technology, fast Internet connection, uninterrupted supply of electricity, maintenance, administration, security and absence of technical support. Bakari, Tarimo, Yngstrom, and Magnusson (2005) assert that most of the developing countries lack quality experts for implementation and maintenance of Information and Communication Technologies (ICT).

- Access to Computers

It refers to the availability of computers for students at all time within the university hours. Equal access requires sufficient computers, and computer labs with calm and peaceful atmosphere. Availability of personal computers at homes is often not a reality for individuals in developing countries. Therefore, unequal access to computers can be a serious challenge to the acceptance of technology by the students. According to Curran (2001), unequal access to online learning indicates inequality not only among the developed and underdeveloped countries, but also inequality amongst the socio-economic groups within a society.

- English Competency

English as a medium for instruction is a serious hindrance for promoting elearning in non English speaking countries like Pakistan. Students having low proficiency are not likely to use e-learning because of low confidence in understanding the contents of English written materials. The study carried out by Shraim \& Khalif (2010) in Palestine found that most of the respondents felt language was a barrier to e-learning. This finding is consistent with studies in other developing countries. For example, the UNESCO (2004) report indicated a need for adequate Thai courseware for e-learning in Thailand.

- Need for Face to Face Interaction

The need of students to have personal engagement with instructors is a significant factor in student satisfaction. However, e-learning often lacks this kind of interaction, which students can have in traditional education systems. Therefore, a balanced approach should be adopted which comprises online 
sessions as well as face to face learning. Sweeney, O'Donoghue, and Whitehead (2004) found similar feelings from their students with significant preference for face to face learning. However, e-learning becomes helpful in learning and sharing of knowledge and diverse competencies across different geographical proximity.

\section{- Level of Awareness}

In the context of information systems, level of awareness is the knowledge of the existence and significance of computer technology. Knowledge and understanding of the e-learning benefits motivate the students to participate. Klamma et al. (2007) suggested that user's satisfaction is closely related to active participation and commitment. Students unaware of the benefits of elearning are likely to get frustrated easily as they may take it as a time wasting activity. Without realizing the importance of a particular technology and its contribution to the achievement of goals, successful integration of technology is difficult.

\section{- $\quad$ Computer Literacy}

According to Croxall and Cummings (2000), the degree of proficiency in computer technology is an important factor in successful adoption of technology. The confidence in skills and ability to use e-learning will contribute significantly towards use of technology. Most likely the more experience the users have in using the Internet and computer, the more likely they will accept and use elearning (Picciano \& Seaman, 2007).

- $\quad$ Resistance to Change

Student resistance shows the degree of negative attitudes towards the use of technology. Research shows that new things are intimidating and they cause resistance or rejection (Jager \& Lokman, 1999). Students studying in a system where they are used to being "spoon fed" are likely to show negative attitudes or even reject e-learning. This dependency on the teachers' presence is likely to induce frustration and dissatisfaction with e-learning. In such cases, students perceive the classroom as the most appropriate place for teaching and learning (Andersson \& Gronlund, 2009). Thus, a shift to the asynchronous approach that is generally used in e-learning is likely to make the students uncomfortable.

- $\quad$ Student Assistance

The demand for e-learning support is likely to grow as e-learning gains popularity, which may strain university resources. More importantly, research indicates that students would register for e-learning based courses only if they have positive attitudes towards technology support (Selim, 2007). Therefore, it is important to have technical staff available all the time for the students.

- Privacy and Security

The growth in web applications, like learning management system, wikis, portal and blogs, requires more efficient ways of providing security for identity management (Alves \& Uhomoibhi, 2010). Furthermore, it is important that the computers have the latest operating systems and software to counter virus attacks. Students are not likely to use infected computers as they will have a trust issue in using applications that require user authentication among other reasons. 


\section{Method}

The source of this data was a questionnaire which comprised questions structured, using a five - point Likert Scale, where $1=$ Strongly Disagree and $5=$ Strongly Agree. The questionnaire was developed on the basis of nine issues identified through in depth literature review and discussion with the students. An open ended question to mention any other relevant e-learning issue was also provided at the end of the questionnaire. Negative statements on the instrument were codified in SPSS to avoid confusion and different interpretation of results.

The population sample for the study was Bachelors, Post- graduate and $\mathrm{PhD}$ students of management sciences department of Iqra University, Islamabad. Participants include morning students as well as evening. Most evening students are working professionals coming with strong knowledge of organizations and their learning culture. Out of 350 questionnaires sent to the instructors, asking them to distribute and picked up from their students during their respective lectures, 238 questionnaires were returned. The respondents were asked to mark the response which best described their level of agreement with the statement. From the 238 questionnaires, 230 were considered useful for analysis, giving a response rate of $65 \%$.

\section{Results}

The results are offered by identifying the most significant e-learning issues experienced by the students by using descriptive and frequency analysis. The mean value of the items was analyzed which helped in detection of the issues. Tables below represent the mean and the response of the students in terms of percentage.

\section{Technical Difficulties}

From Table 1 we can see that Technical Difficulty5 i.e. electricity failure was considered serious issue, with a mean value of 2.17 .

Table 1

Items related to technical difficulties

\begin{tabular}{|c|c|c|c|c|c|c|c|}
\hline \multirow[b]{2}{*}{ Items } & \multirow[b]{2}{*}{ Mean } & \multirow[b]{2}{*}{$\begin{array}{l}\text { Standard } \\
\text { Deviation } \\
\end{array}$} & \multicolumn{5}{|c|}{ Likert Scale Response \% } \\
\hline & & & 1 & 2 & 3 & 4 & 5 \\
\hline Technical Difficulty1 & 3.63 & 0.94 & 2.6 & 10.9 & 21.3 & 51.3 & 13.9 \\
\hline Technical Difficulty2 & 3.34 & 1.10 & 5.7 & 19.6 & 21.7 & 40.4 & 12.6 \\
\hline Technical Difficulty3 & 3.52 & 1.04 & 3.9 & 13.0 & 26.1 & 40.0 & 16.5 \\
\hline Technical Difficulty4 & 3.39 & 1.04 & 4.3 & 17.8 & 22.2 & 42.6 & 11.3 \\
\hline Technical Difficulty5 & 2.17 & 1.25 & 37.8 & 31.3 & 12.6 & 9.6 & 7.8 \\
\hline
\end{tabular}


Technical Difficulty1: Sufficient hardware and software technology is available to use elearning.

Technical Difficulty2: There exist reasonably fast and constant internet services in my University.

Technical Difficulty3: Mode of Internet access from outside the university (e.g. Dial up, ADSL, etc.) is fast.

Technical Difficulty4: Downloading the web content of e-learning does not take much time.

\section{Access to Computers}

Table 2 shows that $41.3 \%$ of the respondents disagree and $19.6 \%$ strongly disagree with the availability of sufficient computers in the University. Whereas $33.9 \%$ felt that the computer labs are noisy and crowded.

Table 2

Items related to access to computer

\begin{tabular}{|l|c|c|ccccc|}
\hline & & Standard & \multicolumn{6}{|c|}{ Likert Scale Response \% } \\
& Mean & Deviation & 1 & 2 & 3 & 4 & 5 \\
\hline Access to Computer1 & 2.30 & 0.91 & 19.6 & 41.3 & 29.1 & 9.1 & .9 \\
\hline Access to Computer2 & 2.91 & 1.01 & 7.4 & 28.7 & 33.9 & 25.2 & 4.8 \\
\hline Access to Computer3 & 2.58 & 1.14 & 17.4 & 33.9 & 22.2 & 18.3 & 5.2 \\
\hline
\end{tabular}

Access to Computer1: There are sufficient computers in the computer labs in my university.

Access to Computer2: I have no difficulty accessing and using an e-learning system in the university.

Access to Computer3: The computer labs are crowded and noisy. (Reverse Codified)

\section{English Competency}

As confirmed by previous researchers, students' proficiency in English was identified as a significant issue with a mean value of 2.53. In order to reduce response biases the item "English Competencyl" i.e. difficulty in reading English, was recorded. Therefore, $46.5 \%$ of the students felt that understanding English is challenge in e-learning, as shown in Table 3.

English Competency1: I feel difficulty in reading English documents. (Reverse Codified)

English Competency2: I can easily understand the teaching material provided to me online. 
Table 3

Items related to English competency

\begin{tabular}{|c|c|c|c|c|c|c|c|}
\hline \multirow[b]{2}{*}{ Items } & \multirow[b]{2}{*}{ Mean } & \multirow{2}{*}{$\begin{array}{l}\text { Standard } \\
\text { Deviation }\end{array}$} & \multicolumn{5}{|c|}{ Likert Scale Response \% } \\
\hline & & & 1 & 2 & 3 & 4 & 5 \\
\hline $\begin{array}{l}\text { English } \\
\text { Competency1 }\end{array}$ & 2.53 & 1.02 & 11.3 & 46.5 & 24.8 & 11.3 & 5.7 \\
\hline $\begin{array}{l}\text { English } \\
\text { Competency2 }\end{array}$ & 3.27 & 1.09 & 4.8 & 22.6 & 24.3 & 35.7 & 12.2 \\
\hline
\end{tabular}

\section{Need for Face to Face Interaction}

Most of the respondents preferred face to face interaction. As shown in the Table 4. The highest percentage was found in the "Agree" category at $47.4 \%$ and $24.8 \%$ in the category "Strongly agree".

Table 4

Items related to need for face to face interaction

\begin{tabular}{|c|c|c|c|c|c|c|c|}
\hline \multirow[b]{2}{*}{ Items } & \multirow[b]{2}{*}{ Mean } & \multirow{2}{*}{$\begin{array}{l}\text { Standard } \\
\text { Deviation }\end{array}$} & \multicolumn{5}{|c|}{ Likert Scale Response \% } \\
\hline & & & 1 & 2 & 3 & 4 & 5 \\
\hline $\begin{array}{l}\text { Need for } \\
\text { Face to Face } \\
\text { Interaction1 }\end{array}$ & 3.31 & 1.08 & 3.9 & 20.9 & 25.2 & 33.5 & 13.0 \\
\hline $\begin{array}{l}\text { Need for } \\
\text { Face to Face } \\
\text { Interaction2 }\end{array}$ & 3.31 & 1.10 & 3.9 & 22.6 & 25.2 & 31.7 & 14.8 \\
\hline $\begin{array}{l}\text { Need for } \\
\text { Face To Face } \\
\text { Interaction3 }\end{array}$ & 3.94 & 0.98 & & 3.9 & 22.2 & 47.4 & 24.8 \\
\hline
\end{tabular}

Need for Face to Face Interaction1: I find it difficult to learn online. (Reverse Codified)

Need for Face to Face Interaction2: I find it difficult to communicate effectively Online. (Reverse Codified)

Need for Face to Face Interaction3: I prefer more personal interaction.

\section{Level of Awareness}

The level of awareness among the students was found encouraging as most of them were aware of e-learning and its use. However, Table 5 presents a mean value of 2.92 in "Level of Awareness3", showing neutral attitude towards the use of new things when old things are working. 
Table 5

Items related to level of awareness

\begin{tabular}{|l|l|l|lllll|}
\hline & & & Standard & \multicolumn{5}{|l|}{ Likert Scale Response \% } \\
Items & Mean & Deviation & 1 & 2 & 3 & 4 & 5 \\
\hline Level of Awareness1 & 3.31 & 1.06 & 3.5 & 22.2 & 25.2 & 36.1 & 12.2 \\
\hline Level of Awareness2 & 3.53 & 0.98 & 3.0 & 13.3 & 25.2 & 44.8 & 13.9 \\
\hline Level of Awareness3 & 2.92 & 2.92 & 16.5 & 23.9 & 22.6 & 23.9 & 12.6 \\
\hline
\end{tabular}

Level of Awareness1: I have known about e-learning for a long time.

Level of Awareness2: Most of my colleagues have utilized or are making use of elearning.

Level of Awarenes3: I like to try new things even when old things are giving good output.

\section{Computer Literacy}

Unlike previous research from developing countries, computer literacy among the students is quite high in this study. Table 6 shows that most of the students believe that they have the necessary skills and required knowledge to use e-learning systems.

\section{Table 6}

Items related to computer literacy

\begin{tabular}{|l|l|l|llllll|}
\hline & & Mean & $\begin{array}{l}\text { Standard } \\
\text { Deviation }\end{array}$ & 1 & 2 & 3 & 4 & 5 \\
\hline Items & 3.93 & 0.86 & .9 & 7.0 & 14.3 & 53.5 & 23.9 \\
\hline Computer Literacy1 & 3.9 & 0.93 & 4.3 & 1.7 & 5.2 & 48.7 & 40.0 \\
\hline Computer Literacy3 & 4.03 & 0.86 & 1.3 & 3.9 & 16.1 & 47.4 & 31.3 \\
\hline
\end{tabular}

Computer Literacy1: I have the necessary skills for using an e-learning system.

Computer Literacy2: I am able to search for information on the Internet.

Computer Literacy3: I understand the differences between online learning and traditional learning.

\section{Resistance to Change}

Table 7 shows that most of the respondents felt that they are motivated to learn online and studying through e-learning is a good idea. 
Table 7

Items related to resistance to change

\begin{tabular}{|l|l|l|llllll|}
\hline & & & & \multicolumn{5}{|l|}{ Likert Scale Response \% } \\
Items & Mean & $\begin{array}{l}\text { Standard } \\
\text { Deviation }\end{array}$ & 1 & 2 & 3 & 4 & 5 \\
\hline Resistance to Change1 & 4.0 & 0.93 & 2.6 & 4.3 & 14.8 & 46.1 & 31.7 \\
\hline Resistance to Change2 & 3.81 & 0.97 & 3.0 & 6.1 & 21.3 & 44.8 & 23.9 \\
\hline Resistance to Change3 & 3.46 & 0.93 & 2.6 & 10.9 & 36.5 & 34.3 & 13.5 \\
\hline
\end{tabular}

Resistance to Change1: Studying through e-learning is a good idea.

Resistance to Change2: I am motivated to learn online.

Resistance to Change3: I intend to check announcements from e-learning systems frequently.

\section{Student Assistance}

Table 8 shows the respondents' view about the assistance provided to them in the University. $34.8 \%$ of students disagree and $17.4 \%$ strongly disagree that there is adequate availability of full time technical staff assistance provided to students in the university. However, the students' response toward the University's commitment to provide assistance was neutral.

\section{Table 8}

Items related to student assistance

\begin{tabular}{|l|l|l|lllll|}
\hline & & & \multicolumn{5}{|l|}{ Likert Scale Response \% } \\
& Mean & $\begin{array}{l}\text { Standard } \\
\text { Deviation }\end{array}$ & 1 & 2 & 3 & 4 & 5 \\
\hline Student Assistance1 & 3.20 & 0.94 & 4.3 & 16.1 & 40.0 & 32.6 & 6.5 \\
\hline Student Assistance2 & 3.08 & 1.20 & 10.9 & 21.7 & 27.8 & 25.2 & 13.5 \\
\hline Student Assistance3 & 2.51 & 1.04 & 17.4 & 34.8 & 29.6 & 14.3 & 3.5 \\
\hline
\end{tabular}

Student Assistance1: University's spending in support of students' IT needs for elearning is adequate.

Student Assistance2: Providing IT support to students' for e-learning is a priority.

Student Assistance3: Full time technical staff provides students with technical support. 


\section{Privacy and Security}

"Privacy \& Security2"- virus in university computers has the lowest mean value among all the criteria. From Table 9, we can see that high percentage of students' consider viruses as a threat to university work.

Table 9

Items related to privacy and security

\begin{tabular}{|l|l|l|lllll|}
\hline & & & Standard & \multicolumn{5}{|c|}{ Likert Scale Response \% } \\
& Mean & Deviation & 1 & 2 & 3 & 4 & 5 \\
\hline Privacy \& Security1 & 3.89 & 0.98 & 3.0 & 6.5 & 17.0 & 45.2 & 28.3 \\
\hline Privacy \& Security2 & 2.01 & 1.05 & 35.7 & 42.2 & 11.3 & 7.0 & 3.9 \\
\hline Privacy \& Security3 & 3.40 & 0.98 & 3.7 & 10.7 & 26.7 & 34.8 & 8.9 \\
\hline
\end{tabular}

Privacy \& Security1: There are good reasons to regulate computer use with username and password.

Privacy \& Security2: Viruses in university computers are great threat to university work. (Reverse Codified)

Privacy \& Security3: I am aware of existing standards which can be used to support privacy/data protection requirements in an e-learning context.

\section{Computer Proficiency and Frequency to Surf Internet}

Table 10 shows the respondent's computer proficiency and frequency of surfing internet. $43.5 \%$ of the students rated their computer skills high and $38.7 \%$ rated their frequency to use internet as high. High mean values and high percentage of computer proficiency and frequency to surf internet is a positive sign towards use of e-learning.

\section{Table 10}

Items related to computer proficiency and frequency to surf internet

\begin{tabular}{|c|c|c|c|c|c|c|c|}
\hline Items & Mean & $\begin{array}{l}\text { Standard } \\
\text { Deviation }\end{array}$ & $\begin{array}{l}\text { Like } \\
1\end{array}$ & $\mathrm{t} \mathrm{Sc}$ & $\begin{array}{c}\text { le Res } \\
3\end{array}$ & $\begin{array}{c}\text { onse } \\
4 \\
4\end{array}$ & 5 \\
\hline Computer Proficiency & 3.60 & 0.81 & 1.7 & 3.5 & 39.1 & 43.5 & 12.2 \\
\hline Frequency to Surf Internet & 3.80 & 0.86 & .4 & 4.3 & 33.0 & 38.7 & 23.5 \\
\hline
\end{tabular}

Computer Proficiency: how would you rate your proficiency at computer use?

Frequency of Surfing Internet: how would you rate the frequency at which you surf the internet? 


\section{Discussion}

All the factors were not deemed as significant issues by the respondents, which show an encouraging trend in a developing country like Pakistan. However, there are still technical, language, computer access, personal interaction, technical assistance and privacy issues.

The absence of secure virus free computers appeared to be a dominant issue in elearning. However, the high computer frequency of use depicts that users do not fear to lose their work because of viruses. It could be because availability of personal computers at homes in developing countries is not very common. This leaves only university labs as the possible place for the students to use systems. Therefore, it increases the need for the institutions to provide sufficient computers to the students along with proper working environment, full time staff for technical assistance with uninterrupted supply of power. As observed, a majority of the factors working against e-learning adoption in Pakistan are related to cost and planned approach towards technology integration. It requires a systematic approach and plan to implement and integrate technologies within the existing systems (Sife, Lwoga, \& Sanga , 2007).

Difficulty in understanding English can be crucial in engaging students in learning. Low confidence in understanding the content deters students' participation. Also, it strengthens students' trust of the traditional educational system where face to face interaction with the teacher tends to lessen the language barrier issues. Consequently, the students may feel uncomfortable when forced to shift from traditional instructor led teaching style to e-learning (Andersson \& Gronlund, 2009).

\section{Conclusion and recommendations}

ICT with its huge potential to improve learning and education at a lower cost imposes a number of support requirements which must be addressed by institutions introducing elearning. The benefits of e-learning are believed to be great enough to allow the governments of developing countries to meet the growing need of education effectively. Therefore, it is crucial for educational institutions and governments to address the above mentioned issues in the most effective manner for the specific country contexts. Some possible strategies to confront these challenges include:

1. The problem of limited funds can be addressed by using open source software and receiving funding from the government and public-private partnerships, as some basic investment in technological infrastructure is required to reap the benefits of ICT.

2. Blended learning techniques involving a balanced mix of face to face interactions, self paced learning and online interactions. This would help the students in getting accustomed to the new ways of learning gradually.

3. Setting up national e-learning development centers focusing on the development and coordination of e-learning activities within the educational institutions.

Thus, high level of e-learning awareness already shows that it has been accepted as an effective mode of delivering instruction. Educational institutions and governments need to coordinate their efforts to address the existing issues in order to promote and support e-learning initiatives. 


\section{References}

Allen, M. W. (2011). Michael Allen's 2012 e-learning annual. Pfeiffer. ISBN 978-0-47091382-6.

Alves,. P., \& Uhomoibhi, J. (2010). Issues of e-learning standards and identity management for mobility and collaboration in higher education. Campus-Wide Information Systems, 27( 2), 79-90.

Al-Mahmood, R., \& McLoughlin, C. (2004). Re-learning through e-learning: Changing conceptions of teaching through online experience. Proceedings of the 21 st ASCILITE Conference (pp. 37-47). Perth. Retrieved from http://www.ascilite.org.au/conferences/perth04/procs/al- mahmood.html.

Andersson, A., \& Grönlund, ^. (2009). A Conceptual framework for e-learning in Developing countries: A critical review of research challenges. The Electronic Journal of Information System in Developing Countries, 38(8), Retrieved from http://www.ejisdc.org/ojs2/index.php/ejisdc/article/viewFile/564/291.

Anwar, M., Greer, J., \& Brooks, C. (2006). Privacy enhanced personalization in elearning. In Proceedings of the 2006 International Conference on Privacy, Security, and Trust, Markham, Ontario, Canada.

Anwar, M., Hukamdad., \& Niwaz, A.(2011). Experience of e-learning in Pakistan: Perceptions and suggestions of graduate students. International Journal of Academic Research. 3(3), 373-376.

Bakari, J. K., Tarimo, C. N., Yngstrom, L., \& Magnusson, C. (2005). State of ICT security management in the institutions of higher learning in developing countries: Tanzania case study. Paper presented at the Fifth IEEE International Conference on Advanced Learning Technologies (ICALT'05).

Concannon, F., Flynn, A., \& Campbell, M. (2005). What campus-based students think about the quality and benefits of e-learning. British Journal of Educational Technology, 36(2), 501-512.

Croxall, K., \& Cummings, M. N. (2000). Computer usage in family and consumer sciences classrooms [Electronic Version]. Journal of Family and Consumer Sciences Education, 18(1), 9-18.

Cysewski, S. (2010). E learning ideas. Retrieved from http://www.cysewski.com/sabbatical/elearningexamples.

Curran, C. (2001). The phenomenon of online learning. European Journal of Education, $36(2), 113-132$.

Economic Survey. (2010). Education. Ministry of Finance, Government of Pakistan. Retrieved from http://www.finance.gov.pk/survey/chapter 10/10 Education.pdf.

Elloumi, F. (2004). Value chain analysis: A strategic approach to online learning. In A. Anderson \& F. Elloumi (Eds.), Theory and practice of online learning (pp. 61-92). Athabasca, Canada: Athabasca University.

Esichaikul, V., Lamnoi, S., \& Bechter, C. (2011). Student modelling in adaptive elearning systems. Knowledge Management \& E-Learning: An International Journal (KM\&EL), 3(3), 342-355.

Garrison, D., \& Anderson, T., (2003). e-Learning in the 21st Century: A framework for research and practice. Routledge, New York.

Huntington, A., \& Sudbery, J. (2005). Experiences of European collaborative teaching and learning. Social Work Education, 24(3), 363-371.

Iqbal, M. J., \& Ahmed, M.(2010). Enhancing quality of education through e-learning: The case study of Allama Iqbal Open University. The Turkish online journal of distance ducation, 11(1), article 5.

Jager, A. K., \& Lokman, A. H. (1999). Impacts of ICT in Education: The Role of the Lecturer and Lecturer Training. Paper presented at the European Conference on 
Educational Research in Lahti, Finland.

Johns, R. (2003). Application of web-based learning in teaching social work law. Social Work Education, 22(5), 429-443.

Klamma, R., Chatti, M. A., Duval, E., Hummel, H., Hvannberg, E. H., Kravcik, M., Law, E., Naeve, A., \& Scott, P. (2007). Social software for life-long learning. Educational Technology \& Society, 10(3), 72-83.

Lewis, D., \& Allen, B. (2005). Virtual learning communities: A guide to practitioners. Maidenhead: Open University Press.

McConnell, D. (2006). e-Learning groups and communities. Maidenhead: Open University Press.

Ndubisi, N., (2004). Factors influencing e-learning adoption intention: examining the determinant structure of the decomposed theory of planned behaviour constructs. In Proceedings of HERDSA Conference, Miri, Malaysia.

Picciano, A., \& Seaman, J. (2007). K-12 online learning: A survey of U.S. school district administrators. New York, USA: Sloan-C.

Roy, A., \& Raymond, L. (2005). e-Learning in support of SMEs: Pipe dream or reality. Proceedings of 5th European Conference on E-Learning (pp. 283).

Saadé, R. G. (2003). Web-based education information system for enhanced learning, EISL: Student assessment. Journal of Information Technology Education, 2, 267-277.

Selim, H. M. (2007). Critical success factors for e-learning acceptance: Confirmatory factor models. Computers \& Education, 49 (2), 396-413.

Shraim. K., \& Khlaif. Z. (2010). An e-learning approach to secondary education in Palestine: Opportunities and challenges. Information Technology for Development, 16(3), 159-173

Sife, A. S., Lwoga, E. T., \& Sanga, C. (2007). New technologies for teaching and learning: Challenges for higher learning institutions in developing countries. International Journal of Education and Development using ICT, 3(2), 57-67.

Surry, D. W., Ensminger, D. C., \& Haab, M. (2005). A model for integrating instructional technology into higher education. British Journal of Educational Technology, 36(2), 327-329.

Sweeney, J., O'Donoghue, T., \& Whitehead, C. (2004). Traditional face-to-face and webbased tutorials: a study of university students' perspectives on the roles of tutorial participants. Teaching in Higher Education, 9(3), 311-323.

UNESCO. (2004). Integrated ICT into education: Lesson learned. UNESCO Asia and Pacific Regional Bureau for Education, Bangkok, Thailand. Retrieved from http://www.gesci.org/old/files/docman/ICT_integrating_education.pdf. 